\title{
Methods of the National Nutrition Survey 1999
}

\author{
Elsa Resano-Pérez, MD, (1) Ignacio M éndez-Ramírez, PhD, (2) Teresa Shamah-Levy, BSc, ${ }^{(3)}$ \\ Juan A Rivera, MS, PhD, ${ }^{(3)}$ Jaime Sepúlveda-A mor, MD, D Sc. . $^{(3)}$
}

\section{Resano-Pérez E, Méndez-Ramírez I, Shamah-LevyT, Rivera JA, Sepúlveda-Amor J. Methods of the National Nutrition Survey 1999. Salud Publica Mex 2003;45 suppl 4:S558-S564. The English version of this paper is available too at: http://www.insp.mx/salud/index.html}

\begin{abstract}
A bstract
Objective. To describe the methods and analyses of the $1999 \mathrm{~N}$ ational N utrition Survey (N N S-99). Material and Methods The 1999 N ational N utrition Survey (N N S-99) is a probabilistic survey with nationwide representativity. The N N S-99 included four regions and urban and rural areas of Mexico. The last sampling units were households, selected through stratified cluster sampling. The study population consisted of children under five years of age, schoolage children (6-11 years), and women of childbearing age (12-49 years). D ata were collected on anthropometric measurements, hemoglobin levels, morbidity and its determinants, and socioecono mic and demo graphic characteristics. In addition, data on diet and micronutrients intakes (iron, zinc, vitaminA, folic acid, vitamin C, and io dine) were obtained in a sub-sample of subjects. Results. The response rate for the N N S-99 was 82.3\%; the non-response rate was $5.9 \%$ and the remaining did not participate due to uninhabited houses. Conclusions This survey updates the information on nutritional status in Mexico and should serve as the basis for food and nutrition policy-making and priority program design. The English version of this paper is available too at: http://ww w.insp.mx/salud/index.html
\end{abstract}

Key words: national surveys; nutrition; children; women; anthro po metry; anemia; micronutrients; diet; Mexico

\author{
Resano-Pérez E, Méndez-Ramírez I, Shamah-LevyT, \\ Rivera JA, Sepúlveda-Amor J. \\ Metodología de la Encuesta Nacional de Nutrición 1999. \\ Salud Publica Mex 2003;45 supl 4:S558-S564. \\ El texto completo en inglés de este artículo también \\ está disponible en: http://www.insp.mx/salud/index.html
}

\section{Resumen}

Objetivo. D escribir la metodo logía y análisis de la Encuesta N acional de N utrición 1999 (EN N-99). Material y metódos. La EN N -99 es probabilística, con representatividad nacional de cuatro regiones y estratos urbano/rural. Las unidades últimas de muestras son los hogares seleccionados por muestreo estratificado y por conglomerados. La población de estudio fueron los niños menores de cinco años de edad, los niños 6-11 años (escolares) y las mujeres de 12-49 años, en quienes se obtuvieron mediciones antro po métricas, niveles de hemoglobina, información sobre morbilidad y sus determinantes, datos socieconómicos y demográficos, y en una submuestra se determinaron micronutrimentos (hierro, zinc, vitamina $A$, ácido fólico, vitamina $C$, yoduria) y se obtuvo información sobre dieta.Resultados. La Encuesta obtuvo una tasa de respuesta de $82.3 \%$, la no respuesta se asoció en $5.9 \%$ a no respuesta del informante y el resto fue ocasionado por no estar habitadas las viviendas seleccionadas. Conclusiones La información obtenida a través de esta encuesta actualiza la información existente en nuestro país y es la base para la formulación de políticas y programas prioritarios. El texto completo en inglés de este artículo también está disponible en:http://www.insp.mx/ salud/index.html

Palabras clave: encuestas nacionales; nutrición; niños; mujeres; antropometría; anemia; micronutrimentos; dieta; México

(1) Secretaría Académica, Instituto N acional de Salud Pública. Cuernavaca, Morelos, México.

(2) Instituto de Investigaciones en Matemáticas A plicadas, Universidad N acional Autónoma de México. México, DF, México.

(3) Centro de Investigación en N utrición y Salud, Instituto N acional de Salud Pública. Cuernavaca, Morelos, México.

Received on: A ugust 20,2002 • Acepted on: July 4, 2003

Address reprint requests to: Maestra Elsa Resano Pérez. Avenida Universidad 655, colonia Santa María A huacatitlán 62508. Cuernavaca, Morelos, México. E-mail: eresano@ correo.insp.mx 
$\mathrm{T}$ he first national probabilistic nutrition and diet survey in Mexico was carried out in 1988. The National Nutrition Survey $1988^{1}$ (NNS-1988) described the nutrition situation for the first time, both nationwide and by region (the country was divided into four regions for that purpose). Surveys previous to 1988 and other recent surveys had excluded either urban or rural zones and had not included representative samples, thus limiting their scope. Unlike those surveys, the NNS-1988 included both urban and rural zones. Also, its probabilistic sampling design made it representative at the national and regional level.

During the NNS-1988, data were collected from children $<5$ years of age, and women of reproductive age, the groups considered to be the most nutritionally vulnerable. Reliability of anthropometric measures was assured through collection by well-trained and standardized personnel. Height and weight measurements, together with age data, could be used for constructing indicators to differentiate between types of malnutrition.

The NNS-1988 collected data from over 13000 households, including 19000 women aged 12-49 years and almost 7500 children $<5$ years of age. Data were collected from women and children on anthropometric measures, dietary intake, sociodemographic characteristics, and health and illness indicators. Data on anemia were collected from women only.

A second NNS was carried out 10 years after the first one, to account for demographic and socioeconomic changes that were likely to be influencing the prevalence and distribution of malnutrition due to deficiency of nutrients and overweight. It was necessary to update the information on the nutritional status of the population, given the high prevalence of malnutrition and overweight found in the previous survey. This paper presents the methods of the 1999 National Nutrition Survey.

\section{Material and Methods}

The study population consisted of Mexican subjects residing in their households at the time of the study, of the following age groups: children $<5$ years of age, school-age children (5-11 years), and women aged 12-49 years. The survey was conducted between October 1998 to March 1999. It included the entire country, aggregated by localities with $<2500$ inhabitants, ${ }^{*}$

\footnotetext{
* Instituto Nacional de Estadística Geografía e Informática establishes an operational definition of rural localities as those $<2500$ inhabitants and of urban localities as those $>2500$ inhabitants, according to the last National Household Sampling Frame of INEGI.
}

$<15000$ inhabitants, and 15000 or more inhabitants, as well as into four regions.*

The survey included diverse data collection strategies for the different age groups. Table I describes collection strategies, surveyed population, and type of data collected. Three different samples are readily apparent in Table I. The original sample included the entire study, with the following data: household characteristics, morbidity, anthropometry, capillary blood sample, and breastfeeding and complementary feeding of children $<2$ years.

A sub-sample was characterized by application of a food questionnaire and a women's questionnaire. A sub-sample of the sub-sample selected for dietary assessment was utilized to obtain a venous blood sample, a urine sample, and table salt intake.

\section{Sample design}

The probabilistic nature of the sample allowed making inferences to the target population and ensured the quality of estimations, mainly presented as rates, means, and proportions.

The sampling frame corresponded to the National Household Sampling Frame of INEGI. ${ }^{2}$ This sampling frame was constructed by stratifying within each Mexican state to demarcate zone grouping localities. ${ }^{\ddagger}$

\section{Construction of sampling units}

Primary sampling units. The primary sampling units (PSU) consisted of one or part of one Basic Geographical Statistical Area (BGSA). This is described as the geographical reference area for statistical information, in localities with 2500 or more inhabitants it is made up of a number of household blocks delimited by streets and avenues (urban BGSA). Localities with $<2$ 500 inhabitants form a rural BGSA within a geograph-

\footnotetext{
* North: Baja California, Baja California Sur, Coahuila, Chihuahua, Durango, Nuevo León, Sonora, Tamaulipas; Center: Aguascalientes, Colima, Guanajuato, Jalisco, México (excluding municipalities and localities adjoining México City), Michoacán, Morelos, Nayarit, Querétaro, San Luis Potosí, Sinaloa, Zacatecas; South: Campeche, Chiapas, Guerrero, Hidalgo, Oaxaca, Puebla, Quintana Roo, Tabasco, Tlaxcala, Veracruz, Yucatán and México City (México City and adjoining urban municipalities of the State of México).

$\ddagger$ Zone I: Cities and metropolitan areas selected for the National Survey of Urban Employment (ENEU); Zone II: Other cities of 100000 and more inhabitants or state capitals; Zone III: Localities with 20000 to 99999 inhabitants; Zone IV: Localities with 15000 to 19999 inhabitants Zone V: Localities with 2500 to 14999 inhabitants; Zone VI: Localities with $<2500$ inhabitants.
} 
Table I

Data collection strategies for the Different age groups. Mexico, 1998-1999

\begin{tabular}{|c|c|c|}
\hline Strategy & Surveyed population & Data collected \\
\hline Q uestionnaire applied at the household & All household members & $\begin{array}{l}\text { Socioeconomic and demographic family charac- } \\
\text { teristics }\end{array}$ \\
\hline Q uestionnaire on morbidity & $\begin{array}{l}\text { Children }<5 \text { years of age, school-age children ( } 5-11 \\
\text { years), and women aged 12-49 years }\end{array}$ & $\begin{array}{l}\text { A cute and chronic morbidity, its determinant fac- } \\
\text { tors and health-seeking behaviors }\end{array}$ \\
\hline Anthropometric measurements & Children $<12$ years of age and women aged $12-49$ years & $\begin{array}{l}\text { Weight and height (in women, waist and hip cir- } \\
\text { cumferences) }\end{array}$ \\
\hline Capillary blood samples & Children $<12$ years of age and women aged $12-49$ years & Hemoglobin concentration \\
\hline Q uestionnaire on children's feeding & Children $<2$ years of age & Complementary feeding and breastfeeding \\
\hline $\begin{array}{l}\text { Q uestionnaire on dietary intake } 1 \text { day be- } \\
\text { fore the visit }\end{array}$ & $\begin{array}{l}\text { Sub-samples* }(1 / 5) \text { of 1- to } 4 \text {-year-olds, } 5 \text { - to } 11 \text {-year- } \\
\text { olds and } 12 \text { - to } 49 \text {-year-old women }\end{array}$ & $\begin{array}{l}\text { Food, energy, macronutrient and micronutrient } \\
\text { intake }\end{array}$ \\
\hline Q uestionnaire on food intake frequency & Sub-sample* (1/5) of women aged $12-49$ years & Food intake frequency \\
\hline Women's questionnaire & Sub-sample* (1/5) of women aged 12-49 years & $\begin{array}{l}\text { O bstetric history, physical activity, and use of to- } \\
\text { bacco and alcohol }\end{array}$ \\
\hline Venous blood and urine samples & $\begin{array}{l}\text { Sub-samples* }(1 / 10) \text { of } 1 \text { - to } 4 \text {-year-olds, } 5 \text { - to } 11 \text {-year- } \\
\text { olds and } 12 \text { - to } 49 \text {-year-old-women }\end{array}$ & Assessment of micronutrient status \\
\hline
\end{tabular}

ical area of about 10000 hectares (BGSA rural) or of several adjoining BGSAs when the number of households was less than the required number to form a PSU. Depending on the zone, they were conformed as follows: zone I PSU: A BGSA with at least 480 households -the combination of two or more adjoining BGSA from the same stratum, with at least 480 households-; zones II to VI PSU: A BGSA or the combination of two or more BGSA with at least 280 households in localities with 2 500 or more inhabitants, or 100 households in localities with $<2500$ inhabitants.

Secondary sampling units. The secondary sampling unit (SSU) in zone I was composed of one or more complete and adjacent blocks with at least 40 inhabited households. In zones II through VI, the SSU consisted of private households.

Tertiary sampling units. The tertiary sampling units (TSU) were found only in zone I and consisted of private households.

\section{Stratification}

Once constructed, the PSUs were stratified by an index of socioeconomic status for each locality and zone using the following variables from the Population and Household Census of 1995: percent of literate population aged 6 to 14 years, percent of literate population aged 15 years, percent of households with public sewage system, percent of households with potable water. For zone VI, the variable "percent of households with electricity" was added. The index was the first principal component obtained with the variables for each zone and locality.

\section{Sample size calculation}

The sample size should be sufficient to ensure that estimations are of good statistical quality. In a multiplepurpose survey, the calculation of an adequate sample size for each single purpose may be quite complex due to the number of variables and relationships of interest. Multiple analyses should be approached by selecting the most important variables that have the lowest values, to obtain the minimum sample size required when the event of interest is uncommon in the total population, thus including by default other more common events. The sample size was calculated using the formula: ${ }^{3}$ 


$$
n=\frac{k^{2}}{r^{2}} \cdot \frac{Q}{P} \cdot \frac{D E F F}{(1-\mathrm{TNR}) P H V}
$$

where:

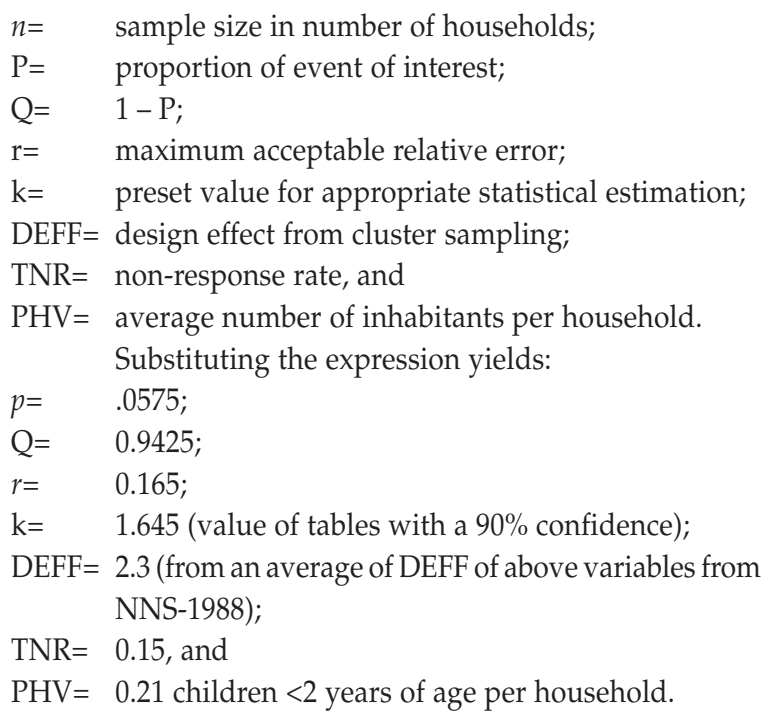

The sample size was $n=2000$ households. The proportions utilized as reference to calculate the sample size came from the National Nutrition Survey 1988 (NNS-1988) and are presented in Table II. A basic variable to calculate the sample size was the proportion of children $<2$ years of age starting milk formula feeding in the first 4 to 5 months of life, since this is an uncommon event representing the smallest study group.

Table III shows the sample distribution by region and locality. Finally, the sub-sample for diet was applied in 4200 households for each of the three intended populations, and the sub-sample for venous blood collection in 2000 households for those three populations.

A multistage, stratified, cluster sampling selection was conducted. In each household, data were collected from all children $<5$ years of age, all school-age children (5-11 years), but only for one woman aged 1249 years.

Households were selected independently in each state/zone. This process varied by zone.

Zone I. In the first stage $\mathrm{n}_{\mathrm{gh}}$ PSU were selected with probability proportional to size (number of households in the PSU in the sampling frame). In the second stage k SSU were selected with probability proportional to size (number of households in the SSU in the sampling frame) in each PSU selected in the first stage.

In each SSU, five households were selected without replacement with equal probability. Thus, the probability of selecting a household was given by:
Table II

Proportions utilized as reference to calculate THE SAMPLE SIZE AS OBTAINED FROM THE NNS-1998. Mexico, 1998-1999

\begin{tabular}{lc} 
Population and type of indicator & Proportion of interest \\
$\begin{array}{l}\text { Population <2 years of age } \\
\text { Perinatal pathologic conditions }\end{array}$ & 0.1530 \\
\hline Absence of breastfeeding & 0.1160 \\
& \\
$\begin{array}{l}\text { Artificial breastfeeding } \\
\text { In the first 4-5 months }\end{array}$ & 0.0575 \\
\hline $\begin{array}{l}\text { Breastfeeding 4-5 months } \\
\text { Population <5 years of age }\end{array}$ & 0.0430 \\
Diarrhea and depressed fontanel & 0.0088 \\
\hline Diarrhea and used antidiarrheal medication & 0.0489 \\
\hline $\begin{array}{l}\text { Diarrhea, the family had no knowledge about } \\
\text { oral rehydration therapy }\end{array}$ & 0.0611 \\
\hline $\begin{array}{l}\text { O ther acute disease } \\
\text { Women aged } 12-49 \text { years } \\
\text { Attended ISSSTE for a medical visit }\end{array}$ & 0.1640 \\
\hline $\begin{array}{l}\text { Presence of diabetes } \\
\text { Pregnant with 31-36 months of time elapsed } \\
\text { between deliveries }\end{array}$ & 0.0373 \\
\hline Receives nutritional supplements from ISSSTE & 0.0074 \\
\hline
\end{tabular}

ISSSTE: Social Security Institute of State Employees

Table III

SAMPLE distribution BY REGION AND LOCALITY. MeXICO, 1998-1999

\begin{tabular}{lrrr} 
Region & $\begin{array}{c}\text { Sample size } \\
\text { in households }\end{array}$ & \multicolumn{1}{c}{$\begin{array}{c}\text { Locality } \\
\text { sample }\end{array}$} & $\begin{array}{c}\text { Sample size } \\
\text { in households }\end{array}$ \\
N orth & 6200 & 15000 or more inhabitants & 10160 \\
\hline Center & 6200 & $<15000$ inhabitants & 10840 \\
\hline South & 6200 & National & 21000 \\
\hline Mexico City & 2400 & & \\
\hline National & 21000 & &
\end{tabular}

$P\left(V_{g h i j}\right)=\frac{n_{g h} m_{g h i}}{m_{g h}} \cdot \frac{k m_{g h i j}}{m_{g h i}} \cdot \frac{5}{m_{g h i j}^{*}}=\frac{5 k n_{g h} m_{g h i j}}{m_{g h} m_{g h i j}^{*}}$

Where:

$\mathrm{n}_{\mathrm{gh}}=\quad$ PSU sample size;

$\mathrm{m}_{\text {ghi }}=$ number of households of the i-th PSU in the h-th stratum of the g-th state; 
$\mathrm{m}_{\mathrm{gh}}=$ number of households in the h-th stratum of the gth state;

$m_{\text {ghij }}=$ number of households in the sampling frame in the j-th SSU of the i-th PSU in the h-th stratum of the g-th state;

$\mathrm{k}=$ SSU sample size, and

$\mathrm{m}^{*}{ }_{\text {ghij }}=$ number of households listed in field work for the $\mathrm{j}$-th SSU of the i-th PSU in the h-th stratum for the g-th state.

Zones II to $\mathrm{V}$. In the first stage $\mathrm{n}_{\mathrm{gh}}$ PSU were selected with probability proportional to size (number of households in the PSU in the sampling frame). In the second stage $t$ households were selected without replacement with equal probability within each PSU selected in the first stage. Thus, the probability of household selection in the $\mathrm{PSU}_{\mathrm{i}}$ is given by:

$$
P\left(V_{g h i}\right)=\frac{n_{g h} \quad m_{g h i} \cdot t}{m_{g h} \quad m_{g h i}^{*}}
$$

Where:

$\mathrm{n}_{\mathrm{gh}}=\quad$ PSU sample size;

$\mathrm{m}_{\text {ghi }}=$ number of households for the i-th PSU within the hth stratum of the g-th state;

$\mathrm{m}_{\mathrm{gh}}=$ number of households within the h-th stratum of the g-th state, and

$\mathrm{m}^{*}{ }_{\text {ghi }}=$ total number of households listed in field work for the i-th PSU within the h-th stratum of the g-th state.

Zone VI. In the first stage $\mathrm{n}_{\text {gh }}$ PSU were selected with probability proportional to size (number of households in the PSU in the sampling frame). In the second stage, there were two or four segments of 10 households on average in each PSU. Therefore, the probability of selecting a household in the $\mathrm{PSU}_{\mathrm{i}}$ of the $\mathrm{h}$ stratum in the $\mathrm{g}$ state was given by:

$$
P\left(V_{g h i}\right)=\frac{n_{g h} \quad m_{g h i} \cdot n_{s e g}}{m_{g h} \quad N_{s e g}}
$$

Where:

$\mathrm{n}_{\mathrm{gh}}=\quad$ PSU sample size;

$\mathrm{m}_{\text {ghi }}=$ number of households for the i-th PSU within the h-th stratum of the g-th state;

$\mathrm{m}_{\mathrm{gh}}=$ number of households in the h-th stratum of the g-th state;

$\mathrm{n}_{\text {seg }}=$ sample size of segments, and

$\mathrm{N}_{\mathrm{seg}}=$ total number of segments constructed in the PSU.

Selection of the sub-sample for dietary data. The sub-sample for diet was selected independently for each study population; one of every five of the 21000 households was selected. In this way, the probability of selecting a household where dietary data were collected for each of the three target populations was given by:

$$
P D\left(V_{g h i j}\right)=P\left(V_{g h i j}\right) \cdot \frac{1}{5}
$$

Where:

$\operatorname{PD}\left(\mathrm{V}_{\text {ghij }}\right)=$ probability of selecting a household for the subsample on diet, and

$\mathrm{P}\left(\mathrm{V}_{\text {ghij }}\right)=$ probability of selecting a household within the j-th SSU within the i-th PSU in the h stratum of the $g$ state.

For the subgroup of women only one woman was selected from those living in a given household; thus, the probability of selecting a woman is given by:

$$
P M=P D\left(V_{g h i j}\right) \cdot \frac{1}{N M V}
$$

Where:

$\mathrm{PM}=$ probability of selecting a woman, and

$\mathrm{NMV}=$ number of women in the household.

Selection of the sub-sample for venous blood data. For each target population, one of every three households was selected from those selected for the diet sub-sample. Venous blood specimens were collected from the target population.

The probability of selecting the household for the venous blood specimen collection was:

$$
P S\left(V_{g h i j}\right)=P D\left(V_{g h i j}\right) \cdot \frac{1}{3}
$$

Where:

$\operatorname{PS}\left(\mathrm{V}_{\text {ghij }}\right)=$ probability of selecting a household for venous blood collection.

\section{Estimates}

The estimate of the total number of characteristic $X$ is given by:

$$
\hat{\mathrm{X}}=\underset{g \sum_{h} \sum}{ }\left(\mathrm{F}_{g h i} \quad \sum_{k} \mathrm{X}_{g h i k}\right)
$$

Where:

salud pública de méxico / vol.45, suplemento 4 de 2003 
Table IV

Fitting of SAmple by Region. MeXico, 1998-1999

\begin{tabular}{ccc} 
& \multicolumn{3}{c}{ Sample fitting in households } \\
\cline { 2 - 4 } & $\begin{array}{c}<500 \\
\text { State }\end{array} 2500$ to 14999 & 15000 or more \\
inhabitants & inhabitants inhabitants Total
\end{tabular}

North

\begin{tabular}{lrrrr} 
Baja C alifornia & 160 & 160 & 350 & 670 \\
\hline Baja California Sur & 80 & 40 & 50 & 170 \\
\hline Coahuila & 240 & 120 & 360 & 720 \\
\hline Chihuahua & 480 & 160 & 410 & 1050 \\
\hline Durango & 480 & 200 & 130 & 810 \\
\hline Nuevo León & 240 & 160 & 630 & 1030 \\
\hline Sonora & 360 & 200 & 290 & 850 \\
\hline Tamaulipas & 360 & 160 & 380 & 900 \\
\hline Total for region & 2400 & 1200 & 2600 & 6200
\end{tabular}

Center

\begin{tabular}{lrrrr} 
A guascalientes & 40 & 40 & 70 & 150 \\
\hline Colima & 40 & 40 & 40 & 120 \\
\hline Guanajuato & 400 & 80 & 290 & 770 \\
\hline Jalisco & 280 & 200 & 480 & 960 \\
\hline México* & 440 & 320 & 990 & 1750 \\
\hline Michoacán & 360 & 200 & 190 & 750 \\
\hline Morelos & 40 & 80 & 100 & 220 \\
\hline N ayarit & 80 & 40 & 50 & 170 \\
\hline Querétaro & 120 & 40 & 70 & 230 \\
\hline San Luis Potosí & 240 & 40 & 120 & 400 \\
\hline Sinaloa & 200 & 80 & 150 & 430 \\
\hline Zacatecas & 160 & 40 & 50 & 250 \\
\hline Total for region & 2400 & 1200 & 2600 & 6200
\end{tabular}

South

\begin{tabular}{|c|c|c|c|c|}
\hline Campeche & 40 & 40 & 80 & 160 \\
\hline Chiapas & 400 & 120 & 230 & 750 \\
\hline Guerrero & 240 & 80 & 270 & 590 \\
\hline Hidalgo & 200 & 80 & 150 & 430 \\
\hline 0 axaca & 360 & 160 & 170 & 690 \\
\hline Puebla & 320 & 240 & 480 & 1040 \\
\hline Q uintana Roo & 40 & 40 & 120 & 200 \\
\hline Tabasco & 160 & 40 & 140 & 340 \\
\hline Tlaxcala & 40 & 80 & 80 & 200 \\
\hline Veracruz & 560 & 240 & 660 & 1460 \\
\hline Yucatán & 40 & 80 & 220 & 340 \\
\hline Total for region & 2400 & 1200 & 2600 & 6200 \\
\hline Mexico City & & 0 & 2360 & 2400 \\
\hline Federal District & 40 & & & \\
\hline Total for region & 40 & 0 & 2360 & 2400 \\
\hline Total number of households & 7240 & 3600 & 10160 & 21000 \\
\hline
\end{tabular}

$\mathrm{F}_{\mathrm{ghi}}=$ expansion factor of the household within the i-th PSU of the $h$ stratum in the g state (inverse of the probability of selecting a household), and

$X_{\text {ghik }}=$ value of the characteristic of interest in the $\mathrm{k}$-th interview within the $\mathrm{i}$-th PSU in the $h$ stratum of the $\mathrm{g}$ state.

The estimation of proportions, rates, and means uses the combined rate estimator $\hat{R}$, given by:

$$
\hat{R}=\frac{\hat{Y}}{\hat{X}}
$$

Where $\hat{Y}$ is defined in a way similar to $\hat{X}$.

The mean squared error for $\hat{R}$ (its squared root is used as a standard error) was obtained with

$\operatorname{MSE}(\hat{R})={ }_{g h}{\frac{n_{h}}{n_{h}-1}}_{i}^{n h}\left(d_{g h i}-\bar{d}_{g h i}\right)^{2}$ where $d_{g h i}=F_{i} F_{h i} \frac{\left(Y_{g h i k}-\hat{R} X_{g h i k}\right)}{\hat{X}}$ IV.

The fitting of sample per region is shown in Table

\section{Data collection results}

Table $\mathrm{V}$ shows that the response rate was $82 \%$ of households. The non-response in $4.46 \%$ of households was due to refusal or to the absence of a proper informant; $13.3 \%$ of households were uninhabited or just temporally inhabited. The response rate per region is also shown.

Data analysis. Data analysis included a socioeconomic index, modified after that proposed by Bronfman, ${ }^{4}$ by weighting different predictors using the principal components method. Predictor variables were: household flooring material, potable water, and ownership of electrical home appliances (washing machine, refrigerator, television, radio, and stove). This index explained 51.6 $\%$ of the variance of the set of variables, with a single component scoring poverty (SES -2.28797 to 1.54518).

\section{References}

1. Sepúlveda-Amor J, Lezana MA,Tapia-C onyer R,Valdespino JL, Madrigal $H$, Kumate J. Estado nutricional de prescolares y mujeres en México: resultados de una encuesta probabilística nacional. Gac Med Mex 1990;126(3):207-225. 
Table V

Response rate in the National Nutrition Survey, Mexico 1999

\begin{tabular}{|c|c|c|c|c|c|c|c|c|c|c|c|}
\hline \multirow{3}{*}{$\begin{array}{l}\text { National } \\
\text { Region }\end{array}$} & \multirow{3}{*}{$\begin{array}{l}\text { Planned } \\
\text { no. of } \\
\text { households }\end{array}$} & \multirow{3}{*}{$\begin{array}{l}\text { House- } \\
\text { holds } \\
\text { visited }\end{array}$} & \multicolumn{9}{|c|}{ Interview results in households } \\
\hline & & & \multicolumn{2}{|c|}{ Response } & \multicolumn{2}{|c|}{$\begin{array}{l}\text { Information- } \\
\text { related } \\
\text { non-response }\end{array}$} & \multicolumn{2}{|c|}{$\begin{array}{c}\text { Uninhabited } \\
\text { temporal } \\
\text { use }\end{array}$} & \multicolumn{2}{|c|}{$\begin{array}{l}\text { Prob. } \\
\text { of } \\
\text { frame }\end{array}$} & \multirow[t]{2}{*}{$\begin{array}{l}\text { Households } \\
\text { with } \\
\text { respondent }\end{array}$} \\
\hline & & & Total & $\%$ & Total & $\%$ & Total & $\%$ & Total & $\%$ & \\
\hline Republic of Mexico & 21000 & 21503 & 17716 & 82.39 & 1260 & 5.86 & 2109 & 9.81 & 418 & 1.94 & 17944 \\
\hline North & 6200 & 6361 & 5430 & 85.37 & 229 & 3.6 & 602 & 9.46 & 100 & 1.57 & 5471 \\
\hline Center & 6200 & 6381 & 5194 & 81.4 & 429 & 6.72 & 652 & 10.22 & 106 & 1.66 & 5212 \\
\hline Mexico City & 2400 & 2411 & 1829 & 75.86 & 285 & 11.82 & 245 & 10.16 & 52 & 2.16 & 1930 \\
\hline South & 6200 & 6350 & 5263 & 82.89 & 317 & 4.99 & 610 & 9.6 & 160 & 2.52 & 5331 \\
\hline
\end{tabular}

* Difference with planned number of households resulting from the updating of the sampling frame during data collection

2. Instituto N acional de Estadística, Geografía, e Informática. Resultados del Conteo de Población y Vivienda de 1995. México, DF: IN EGI, diciembre 1995.

3. Cochran W. Sampling techniques. Third edition. 0 tawa, C anada: John W iley \& Sons, 1977.
4. Bronfman M, G uiscafré H, Castro V, Castro R, G utiérrez G. La medición de la desigualdad: una estrategia metodológica, análisis de las características socioeconómicas de la muestra. Arch Invest Med 1988;19:351-360. 